\title{
Academic publishing and the myth of linguistic injustice
}

Academic publication is now an enormous industry which dominates the professional lives of academics across the globe, with perhaps six million scholars in 17,000 universities producing over 1.5 million peer reviewed articles each year (Bjork et al, 2009). The reach and significance of this industry has never been greater because it is through publication that knowledge is constructed, academics are evaluated, universities are funded, and careers are built, and each year its influence becomes ever more intrusive and demanding. Publication is where individual reputations and institutional funding coincide; the result of managerialism and an accountability culture which seeks to measure 'productivity' in terms of papers, and citations to those papers. In this context 'knowledge' is regarded as a thing which can be parcelled up and measured and those that produce it are seen as deserving of rewards. The more knowledge produced, the greater the reward.

Scholars around the world have therefore found their promotion and career opportunities increasingly tied to an ability to gain acceptance for their work in high profile journals indexed in the Web of Knowledge SCI databases and usually published in English. This counting of output, for example, helps explain the 4-fold increase in submissions to the 4,200 journals using the ScholarOne manuscript processing system between 2005 and 2010 and why this increase is led by academics from countries which have not traditionally been strong in research. So while submissions from traditional publishing powerhouses such as the US and Japan increased by $177 \%$ and $127 \%$ respectively during these 5 years, those from China and India increased by $484 \%$ and $443 \%$, and Iran and Malaysia saw more than $800 \%$ increases in submissions (Thomson Reuters, 2012). Overall, the US share of world submissions dropped by 3.3\% over this period while China`s increased by 5.5\%, moving it from 14th to 5th in world output in just 10 years (Royal Society, 2011). More recent figures from SCImago (2014) show China just behind the US in submissions. 
Submissions, however, are not accepted articles and the dominance of English in academic publishing has raised questions of communicative inequality and the possible 'linguistic injustice' against an author's mother tongue (Clavero, 2010). Native English speakers are thought to have an advantage as they acquire the language naturalistically while second language users must invest more time, effort and money into formally learning it and may experience greater difficulties when writing in English. Attitude surveys reveal that English as an Additional Language (EAL) authors often believe that editors and referees are prejudiced against them for any non-standard language uses while Flowerdew (2008) even claims that EAL writers are "stigmatized" by journal editors and reviewers - the "normal." In this paper I critically examine the evidence for linguistic injustice - or editorial prejudice - through a survey of the literature and a small study of EAL contributions to leading journals. To support my argument I draw on interviews conducted with 25 EAL scholars of various first language backgrounds, disciplines and publishing experience together with a handful of Native English speaking scholars ${ }^{1}$. I argue that framing publication problems as a crude Native vs -non-Native polarisation functions to demoralize EAL writers and ignores the very real writing problems experienced by many L1 English scholars.

\section{Global publishing and disadvantage}

On the face of it, the expansion of international publishing to all corners of the planet is a positive development, both for academics and for developing nations seeking to become part of the "knowledge economy." Globalization offers greater opportunities for increased scholarly dialogue by broadening the corpus of academic literature, providing new avenues for research and collaboration, and opening more channels for reporting location-specific research. The greater participation of multilingual researchers in this web also offers massive benefits to global knowledge itself. As Liu (2004: 2) observes, EAL researchers "help reform, expand, and enrich the knowledge base of core disciplinary communities" and

\footnotetext{
${ }^{1}$ All participants work in a leading research-intensive university in Hong Kong and were interviewed using an open-ended schedule of questions which focused on their educational background, writing challenges, publishing experiences and collaborative writing.
} 
Canagarajah (1996) concurs that these scholars are able to bring outside perspectives to offer fresh insights on old problems. Perez-Llantada (2014: 192) also sees discoursal changes as "Anglophone norms merge with culture-specific linguistic features". Thus the participation of this broader base of researchers in academic publication enriches knowledge, raises previously unexplored issues in the mainstream, enhances rhetorical practices, and draws attention to untapped resources (also Flowerdew, 2001).

Despite the surge in submissions from BRIC (Brazil, Russia, India and China - the 'emerging economies") and other non-established nations, however, the "Western" nations (and Japan), continue to dominate the world output of scientific papers. The United States remains the biggest spender on research and produces the most research papers, accounting for $29 \%$ of the total number of published papers, followed by Japan with $8 \%$ and the United Kingdom, Germany, and China with 6\% each (World Bank, 2012). This means that these five countries are responsible for 55\% of the world's journal articles, while 23 countries accounted for 90\% (Ware \& Mabe, 2009). Thus, while acceptances in Institute for Scientific Information (ISI) ranked journals ${ }^{2}$ for the major players remained fairly stable at around 50\% of submissions between 2005 and 2010, the massive increases in submissions by China and Iran yielded no appreciable increase in accepted papers while India, Taiwan, Korea and Brazil all saw acceptances fall by at least $4 \%$ (Thomson Reuters, 2012). So although increased financial investment has stimulated the participation of EAL researchers in global publishing, this has not had an equal impact on published output or on the influence of their papers as measured by citations to them.

The fact that publication rates have lagged behind increases in submissions does not necessarily mean that the quality of these submissions has not increased, merely the intensity of competition. Numerous

\footnotetext{
${ }^{2}$ The ISI is a unified citation index to the academic literature representing the most prestigious journals. Part of the Thomson Reuters 'Web of Knowledge', the ISI includes databases for the sciences, social sciences and humanities and includes Annual Journal Citation Reports (JCR) which give an Impact Factor (IF) for each journal in its indexes.
} 
obstacles prevent submitted manuscripts becoming published papers and participation in academic publishing clearly makes sophisticated demands on writers. But while all newcomers feel challenged and intimidated by writing for publication, attention has largely focused on the difficulties of non-Anglophone authors. Anecdotal evidence suggests that Native speakers of English are unfairly advantaged in scientific publication by virtue of their Native - non-Native speaker status (e.g., Clavero, 2010; Guardiano et al. 2007) as it is easier for them to access the literature in English and to craft texts linguistically acceptable to the gatekeepers of international journals.

This view receives some support from several quantitative studies which have found that submissions to medical journals from countries with low English proficiency scores, low Gross Domestic Product, or little research funding are less likely to be accepted for publication irrespective of their scientific quality (e.g. Man et al, 2004). Saposnik et al (2014), for example, analyzed all 15,000 contributions submitted to the journal Stroke between 2004 and 2011 and found that acceptance rates were higher for submissions from countries where English was the Native language. Similarly Okike et al (2008) and Ross et al (2006) found a preference for articles from authors in the US and Canada, a preference which was reduced by $34 \%$ with a blinded review process (Ross et al, 2006). It is important to point out that the effects of English proficiency on the clarity or organisation of submitted texts was not examined directly in these studies, but assumed on the basis of where the corresponding authors resided. In fact, Saposnik et al speculate on the reasons for lower acceptance rates from these countries:

It is possible that some reviewers are more critical of the quality of research or give lower priority scores to borderline articles written by non-English speakers. Contrarily, regional constraints (eg, low investment in research, suboptimal research training, limited education in how to write scientific articles, etc.) may also explain the parallel lower submissions and acceptance rates for non-English-speaking countries and for those with low expenditures in research. Other financial incentives (eg, scientists receiving bonuses per performance and submitting higher number of lower quality publications) may also play a role. $\quad$ (Saposnik et al, 2014: 1866) 
This catalogue of possibilities reflects a wider uncertainty about the role of language in the acceptance or rejection of papers for submission.

\section{EAL writer perceptions}

It is certainly the case that many EAL authors report a sense of inequality compared with NES scholars when writing in English. Surveys of Polish (Duszak \& Lewkowicz, 2008), Slovakian (Kurilova, 1998), Mexican (Hanauer \& Englander, 2011), Spanish (Ferguson et al, 2011) and southern/eastern European (Lillis \& Curry, 2010) researchers reveal that many EAL authors feel some sense of disadvantage relative to Anglophone scholars. Almost $80 \%$ of the Mainland Chinese doctoral researchers in Li's (2002) study felt disadvantaged compared with their Native English-speaking counterparts, for example, and Hwang's (2005) Korean academics resented the time it took them to write papers, believing that Native English speakers gained that time for research. Hanauer and Englander (2011), have even sought to quantify this perceived relative burden. Their study of Mexican scholars from a range of scientific disciplines indicates that subjects saw writing a scientific article in English as $24 \%$ more difficult and generating $21 \%$ more anxiety than writing papers in Spanish.

These studies undoubtedly suggest that many writers experience English academic conventions as an impediment and this is often accompanied by a sense of disadvantage in relation to Anglophone scholars. Flowerdew's (1999) questionnaire survey of 600 Hong Kong academics found that over two thirds felt they were at a disadvantage compared with Native English Speakers when writing for publication, with about half citing language issues as the main problem. But while many felt hampered by "less facility in expression" and a "less rich vocabulary", follow-up interviews showed that $75 \%$ were confident that they would get their research published. Perez-Llantada’s (2014) Spanish scholars and Tardy’s (2004) international graduate students also identified problems in having to use English, particularly the time needed to learn English to a high level, but both groups acknowledged the benefits of having a common language for scientific exchange. Murray \& Dingwall's (2001) study of 250 Swiss academics similarly 
found mix responses. While $41 \%$ believed using English was a slight disadvantage, $27 \%$ felt it was an advantage and 24\% saw it as having no effect at all. These results parallel Ammon's (1990) survey of German scientists where $55 \%$ reported no sense of disadvantage.

Overall, then, these surveys offer a mixed picture and reflect the context-dependent nature of attitude surveys, conveying something of the very different support and resource circumstances individuals work under and their own educational experiences and backgrounds. While many respondents complain that writing in English is time-consuming and laborious, substantial numbers feel no disadvantage at all. How authors answer questions about disadvantage are likely to be influenced by who they believe they are in competition with, whether they are asked to assess advantage in normative or moral terms, and how competent they believe they are in English (Ferguson et al, 2011). Nor is it clear whether the respondents are aware of the difficulties experienced by the Native-English speakers they are comparing themselves with or whether they are basing their views on untested assumptions. Even proficient NES academics suspect that others write more easily and quickly than themselves. Personal and national circumstances are also important, so we might expect scholars from small multilingual countries, like Switzerland, to feel less disadvantaged than those from countries with a very different language systems to English, such as Korea and China.

In fact, one of my Hong Kong informants saw the ability to write in several languages as a distinct advantage:

I think monolinguals are trapped in their own language and isolated from so much experience and knowledge. The ability to write and read in several languages can be a real advantage. $\quad$ (Polish speaker - Linguistics)

Another comment summarized much of the attitudinal research:

I wouldn't say English is an obstacle but it's a challenge because it's not my first language. Mastering the academic style is very challenging. Not just knowing how to write grammatical English but whether I can write in such a sophisticated way 
that the reviewers of prestigious journals would like to publish my manuscript.

$$
\text { (Cantonese speaker - Education) }
$$

Attitudes are cross cut by proficiency, first language, discipline and publishing experience and, of course, many EAL authors successfully publish their papers.

\section{Non-Anglophone authors: texts and practices}

The substantial literature reporting EAL authors' perceptions is not matched by studies of submitted texts or the processes used to create them. While several studies have found non-standard uses in EAL texts, the fact they are necessarily small scale and cover a range of different contexts and disciplines makes it difficult to generalize about issues of equity. They show, however, that academic writing in English can present considerable challenges to non-Anglophone scholars, although these do not always prevent them gaining acceptance for their work.

A small comparative study of English language papers published by Sudanese and British medical researchers, for example, found a great deal more adherence to the conventions of impersonalization in the British papers, with more hedging, nominalization and careful explanation (El Malik \& Nesi, 2008). Loi (2010) found that a sample of Chinese research article introductions in educational psychology employed a simpler rhetorical structure compared to those in English, and Burrough-Boenisch (2003) highlights the problems that multilingual authors' may have with word order, word choice, and register. The fact that these studies were conducted using published papers suggests that the problems found were not terminal. In fact, Moreno et al (2012) found that the lower English proficiency levels of their Spanish researchers was only one factor in the difficulties they experienced in writing articles.

In addition to text analyses, there is a body of case study research which has focused on the processes of text creation, pointing to the protracted time and effort needed to write for publication in English (e.g. Lillis \& Curry, 2010; Burrough-Boenisch, 2003). St John (1987), for instance, found that her Spanish 
researchers spent considerable time over precise expression through changes in word order and lexis. Similarly, Gosden (1995) discovered that the research writing practices of junior scientists mainly involved mechanical editing to improve expression, using Japanese-English reference texts. They also translated from their L1 a great deal, often phrase by phrase, and borrowed from expert authors texts. Li's (2006) longitudinal account shows how a Chinese doctoral student of physics slogged through six drafts and several painstaking resubmissions before her paper was finally accepted for publication.

Overall, this research suggests that texts by EAL authors may differ in some regards and that writing may be more laborious for them. Once again, however, we lack the comparative data which might help put these difficulties into perspective. Research into the problems experienced by Anglophone authors is thin on the ground and has only begun to attract scholarly interest relatively recently (e.g. Habibie, 2015; Hyland, 2015). Myers (1990) and Berkenkotter and Huckin (1995), however, document the struggles of even well-published and experienced Native English speaking authors trying to justify the importance of their experiments to a potentially sceptical research community. In short, assertions that EAL authors have greater difficulties in writing than their Native English counterparts are largely speculative - while self-reports tell us it is, we just don't know if it is the case or not. Writing for publication is a specialised competence which both Native and non-Native English speakers must acquire, a fact which is obscured by two key assumptions of the linguistic disadvantage orthodoxy.

\section{Problematic assumption 1: the Native/non- Native divide}

While the need for a certain proficiency in a foreign language inevitably creates an added burden for authors, there are difficulties in framing linguistic disadvantage in terms of a Native/non-Native divide. The Native speaker's advantage is attributed to a combination of "natural" acquisition and the idea that Native speakers own and control their mother tongue. The term, however, has been hotly debated since it was introduced by Bloomfield in the 1930s (e.g., Love \& Ansaldo, 2010). Davies (2003), for example, has offered a critical view of the concept of "Native speaker" and Escudero and Sharwood-Smith (2001) 
suggest we should understand it as a gradient term whereby individuals approximate more or less to a Native-speaker prototype.

Ferguson et al (2011: 42) see two main problems in using the term to frame linguistic disadvantage:

The first is that academic writing, or academic literacy, is not part of the Native speaker's inheritance: it is acquired rather through lengthy formal education and is far from a universal skill. A second is that the non-Native speaker category, like the Native category, is a very loose one, encompassing individuals of very varying levels of proficiency, some of whose languages are linguistically related to English and some of whose are linguistically distant.

While the idea of Native speaker might imply the advantages gained by having internalised the language through "natural acquisition", rather than through deliberate learning, academic English is no one's first language. In fact, "Native-speakerhood" refers more accurately to the acquisition of syntactic and phonological knowledge as a result of early childhood socialization and not competence in writing, which requires prolonged formal education. We don't learn to write in the same way that we learn to speak, but through years of schooling.

The register of academic writing is a specific domain of expertise comprising a sub-set of lexicogrammatical features and rhetorical conventions which have evolved to perform certain valued functions for those who use them. While its regularities and peculiarities vary across disciplines, it is a linguistic code which captures the cultural profile that emerges through the identity investment of academics in creating particular kinds of meanings that insiders will recognize and understand. As a result, many literate and well-educated NESs lack the necessary know-how and experience to produce publishable papers while countless EAL scholars, benefiting from the experience gained from EAP courses and years of doctoral apprenticeship, find themselves more 'academically bilingual' 
Several of my informants in Hong Kong, for example, cited their training and experience as reasons why they actually found it easier to write in English than their first language:

I only publish in English. I think I can only write in English (laughs). Because we were trained to do that all through the PhD years. Then you find you can't write in Chinese. It is not just the writing but thinking about research might be different. That's why, you know, after a while getting used to their way and you wouldn't be able to do a different way. $\quad$ (Cantonese speaker - Business studies)

I am more used to writing in English and for English speaking audiences. I seldom write in Chinese because I don't have time. I have had a few articles translated into Chinese. They are about bilingual education. If I had more time, I would try. It's faster to get someone who is good at it, to translate it than for me to write the paper in Chinese.

(Cantonese speaker -Education)

I don't write in Chinese. Before I did my PhD I taught for a while in Mainland China at a University and I published one or two papers in Chinese but those were not really proper research. Since I came to Hong Kong I have been publishing in English.

(Putonghua speaker - history)

I think it's just the way I have been educated and the way I have been socialized into academia was to write in English, yes. I published one paper a long time ago in Polish but I haven't written in any other language than English since then.

(Polish speaker - linguistics)

The arcane conventions of academic discourse are perhaps equally daunting to Native English speakers who also struggle to produce polished prose (Casanave \& Vandrick, 2003) and US students appear as prone to anxiety about their academic writing as international students (Swales, 2004: 57).

Moreover, with perhaps a quarter of the world's population able to speak English to some degree (Graddol, 2000), labelling any particular individual as a Native or non-Native speaker has become increasingly problematic. There are, moreover, non-Native English speakers in the academic centre at leading research universities as well as at the periphery, and those who have studied in an Englishspeaking country or are members of international research groups as well as those who have never left home. 
Claims of EAL speaker disadvantage are therefore far from straightforward and, in fact, the Native/nonNative distinction seems to break down entirely at advanced levels of academic writing. A corpus study by Römer (2009:99), for example, found that

Native and non-Native apprentice academic writers develop their academic discourse competence in similar ways, and that Native speakers also have to learn the language (and phraseology) of academic writing.

This 'apprenticeship' or 'enculturation' into the norms of academic rhetorical practice is for NES research students, as it can be for NNESs, often a painful and protracted experience. Berkenkotter and Huckin's (1995) detailed case study of Nate, for example, shows an intelligent and reflective Native English speaking student slowly developing an ability to integrate subject matter knowledge with unfamiliar situationally appropriate linguistic and rhetorical conventions. They portray this as a "lengthy and difficult process", largely because it involves the individual acquiring a new and "very clearly structured set of symbols which he can use in locating himself in the world" (Hudson, 1996: 14).

Research shows that a key issue for many novices is the lack of a disciplinary appropriate conceptual framework which allows them to speak with authority: like NNES academics, L1 authors must develop a sense of self as an academic writer (e.g. Badenhurst et al, 2015). Cameron et al (2009) and Shirey (2013), for example, talk of the strong emotions of self-doubt, anxiety and erosion of confidence experienced by novice L1 academic writers, many seriously troubled by the fear of rejection (Oermann \& Hays, 2011). Similarly, Aitchison et al's (2012) study of 36 doctoral students and their supervisors in the sciences found writing to be 'emotional work' which created strong feelings of both joy and pleasure, pain and frustration. None found writing easy or enjoyable and it involved considerable struggles for all of them.

Swales (2004: 56), in fact, argues that the most important distinction in publishing is not between Native and non-Native English speakers but 
between experienced or "senior" researcher/scholars and less experienced or "junior" ones - between those who know the academic ropes in their chosen specialisms and those who are learning them.

Like language proficiency, academic literacy is also a variable competence which develops with practice and experience. Moreno et al's (2012) 1,717 Spanish postdoctoral researchers, for example, felt that the experience of writing for publication in English was far more important than language proficiency in gaining acceptance for papers. Irrespective of whether a writer is a Native or non-Native, craft skills, the ability to navigate submissions and a general publication savvy improve with practice (e.g. Mur Dueñas, 2012).

Experts certainly seem to have the edge over novices in academic text production, with both a greater command of the discipline's rhetorical resources (Hyland, 2011) and understanding of how a paper might best be steered through the review process (e.g. Myers, 1990). Pagel et al (2002), for example, found that postdoctoral fellows in a leading medical research school had greater difficulty with writing and publishing than faculty members. One reason for this is that graduate students struggle to imagine an appropriate audience in constructing arguments which readers find persuasive. Several of my novice researcher informants noted that this was a significant problem for them:

Structuring is pretty complicated for me. I still spend a lot of time trying to think where I should put information and the structure of each section. Let's say with the introduction, how you organize it in a way that makes sense. They don't want too much information but they want enough and in a way they can use.

(biology student)

This was a problem reinforced in interviews with their professors:

A lot of our post docs need a lot of help, a lot of spoon-feeding. Not just what to do in the lab but how to write. They really seem to be at a loss about how to organize the information for journals. $\quad$ (Chemistry prof) These conversations, moreover, demand awareness of the main disciplinary paradigms and the community zeitgeist as writers must address research topics which will interest colleagues, framing their research claims within these topics. 
The Native-non-Native distinction is therefore a crude instrument with which to explain publishing success and to assume that NESs share the same communicative competence ignores the extensive research into the specialist literacy skills demanded by academic writing. We need, then, to separate communicative performance from mother-tongue status when looking at English for publication and to see that expertise develops with practice.

\section{Problematic assumption 2: the primacy of language}

While the stereotype of "non-Native speaker" is frequently invoked to explain the vulnerability of novice EAL writers in the review process, non-discursive physical and financial barriers may well be greater than linguistic ones (e.g. Wood, 2001). The degree of training and experience in scientific writing, geographical location, or even the number and type of collaborators, may be more powerful determinants of publication success. Two key factors here are those of situatedness and isolation.

Despite taking place on a global stage, scholarly writing is always a situated practice which occurs in local academic communities. It is carried out and learnt through very local and concrete interactions with particular texts and particular others and so bares the stamp of specific cultural traditions and ways of seeing problems. This situatedness of the researcher creates powerful affordances for global research as it allows multilingual scholars to bring insider awareness about local contexts or issues that mainstream academic communities are not aware of (e.g. Cho, 2004). It can therefore often seem to be a very peripheral participation indeed to those working alone or on the edge of academic activity.

Academics on the periphery may feel out-of-the-loop on current developments in their field and become frustrated that they are unable to consult with peers and mentors about matters. Gosden, refers to these impediments as isolation which can refer to a range of issues:

The broad term 'isolation' covers many causes, for example: not carefully reading

'Instructions to Authors'; unfamiliarity with the journal and its academic level; not 
previewing previous literature well and relating to others' work, possibly due to a lack of literature/library facilities; a lack of awareness of what constitutes publishable research; and unfamiliarity with the broad (and unwritten) 'rules of the game'. Gosden (1992: 133) This sense of isolation from the mainstream is obviously a major impediment to researchers in Less Developed Countries (LDCs) but also afflicts anyone working 'off-network' in poorly-resourced institutions with small library budgets and little research activity in relatively wealthy parts of the world.

Isolation seems to be felt particularly by junior academics returning to their home countries to take up positions in less prestigious places after completing graduate level study at research intensive universities abroad. They can experience an acute sense of exclusion from the mainstream conversations of the discipline in what Geertz (1983) refers to as the 'exile from Eden syndrome' whereby "one starts [an academic career] at the center of things and then moves toward the edges" (1983:158). Scholars who miss the opportunity to discuss issues with their mentors and attend conferences has been reported for Egyptian (Swales, 1990), Hong Kong (Flowerdew, 2007) and Japanese (Casanave, 1998) returnees. The notions of situatedness and isolation thus help to foreground both the unique contributions multilingual scholars make to global scholarship and the distance they often feel from the centre.

There are various aspects of 'isolation' and a particularly serious hurdle for peripheral scholars is overcoming a lack of up-to-date technologies, poor access to the literature and insufficient funds to conduct appropriate experiments. One of my interviewees spoke of his experience in this way:

When I worked in a (provincial) university in China I faced many challenges always. I had no professor to help me and the library was small. Most articles are not open access and Amazon will not send books to China because of credit card problems. There is no grants. It is very hard to do research. (Chinese student) Restricted access to the literature prevents researchers entering academic conversations in a relevant way, making their contributions sound badly framed or "old news" (Canagarajah, 1996). Not all EAL authors face the same problems of course, nor are these difficulties restricted to EAL academics. Canagarajah 
(1996: 440) notes that his arguments might equally apply "to the periphery within the center: the marginalized communities and poorly facilitated institutions in the technologically advanced nations".

But while Anglophone scholars working in climates of cutbacks to university funding also suffer, it is those researching in less-developed countries who suffer the most. There is, as a result, a statistically significant difference between the high and low income countries in terms of the rejection rate of submitted manuscripts (Patel \& Youl-ri, 2007) with acceptances of only $4.8 \%$ in top psychiatry journals (Singh, 2006) and just 0.3\% in anaesthesiology (Bould et al, 2010) for authors in low income countries?. A study of 400 published clinical trials found a considerable manuscript selection bias against low income countries due to a mistrust of the data (Yousefi-Nooraie, et al, 2006), and it is almost a law of publication that the percentage of articles from Less Developed Countries decreases as the Impact factor of the journal increases (Rohra. 2011). Simply, research conducted in the richest countries is more likely to be accepted for publication with the acceptance rate of papers from countries increasing by $27 \%$ with every million US\$ invested in research (Saposnik et al, 2014).

Peripheral scholars also have to contend with a system which celebrates local knowledge generated in the Anglophone centres of research as an unmarked universal discourse with a claim to global relevance. Several of my informants in Hong Kong recognised the hegemonic status of 'global knowledge': You have to set the study in a bigger context, one that is going to echo with the wider discipline. Nobody is really that interested in what is going on in HK schools, nobody outside HK that is, and you have to put it into their terms. Critical perspectives or how it contrasts to overseas studies. $\quad$ (Applied Linguistics researcher)

Framing the local as global, or as a point of exotic contrast to the centre, is a key strategy helping academics in non-Anglophone locations to secure their work for publication in ISI-indexed venues. Another strategy is working with overseas partners. So, about half the ISI indexed papers with an African-affiliated author are co-authored with partners from outside the continent. In fact, some $85 \%$ of 
the papers published from Mali and Gabon involve collaborations with researchers on other continents (Tijssen, 2007).

In sum, the disadvantages of physical, scholarly and financial isolation may be greater than those of language. Certainly, these factors are frequently associated with poor linguistic skills, at least in nonEnglish speaking periphery countries, but a crude Native vs non-Native dichotomy fails to capture a far more complex picture.

\section{Non-Anglophone authors in international journals}

Despite all the problems, more non-Anglophone researchers are writing successfully for publication than ever before, outnumbering NESs in many fields. In applied linguistics and language teaching, the increase seems particularly marked. Swales (2004: 41), for example, shows "a steady and welcome decline" in the dominance of papers by US authors in TESOL Quarterly, while Hewings (2002) observes a doubling of the articles originating outside the US and UK in English for Specific Purposes. While these applied linguistics journals might be expected to attract more English-proficient submissions, 60\% of articles in The Journal of Thoracic and Cardiovascular Surgery are now from EAL authors (Benfield, 2007) and EAL submissions dominate leading journals like Science and Nature (Wood, 2001).

Medical journals have long been at the forefront of publishing EAL authors, although hard evidence for the same kind of growth in other fields is difficult to find. Table 1 is an initial attempt to offer an indication of changes in this area. This shows the results of a "quick and dirty" study of the five journals with the highest 5 year Impact Factors in each of six disciplines in the hard sciences and social sciences in the decade from 2000 to 2011 . These therefore represent the top cited sources in key academic fields. The categorisation of authorship was based on the family name and country of affiliation of the first author, with the handful of non-Anglo Saxon names in English speaking countries counted as NES. 
While admittedly a rough and ready classification, the figures suggest something of the substantial increase in EAL authors to the growth of published papers over the last decade.

Table 1: First author for articles published in top 5 journals by Impact Factor

\begin{tabular}{lcccc}
\hline & NES & EAL & NES & EAL \\
Biology & $424(61.4 \%)$ & $267(38.6 \%)$ & $740(58.7 \%)$ & $521(41.3 \%)$ \\
Elec Engineering & $214(46.0 \%)$ & $251(54.0 \%)$ & $256(24.7 \%)$ & $780(75.3 \%)$ \\
Physics & $109(27.8 \%)$ & $283(72.2 \%)$ & $714(31.1 \%)$ & $1583(68.9 \%)$ \\
Economics & $340(79.4 \%)$ & $88(20.6 \%)$ & $270(68.5 \%)$ & $124(31.5 \%)$ \\
Linguistics & $288(74.8 \%)$ & $97(25.2 \%)$ & $242(61.2 \%)$ & $153(38.8 \%)$ \\
Sociology & $312(79.0 \%)$ & $83(21.0 \%)$ & $284(69.8 \%)$ & $123(30.2 \%)$ \\
Overall & $1687(61.2 \%)$ & $1069(38.8)$ & $2506(43.3 \%)$ & $3284(56.7 \%)$ \\
\hline
\end{tabular}

The sample shows there were three times more papers overall from EAL authors in 2011 compared with 2000. Physics represents the only decline in the proportion of papers from EAL sources, but this is more than matched by the increase in the number of published articles in this discipline. Overall, EAL submissions are increasingly getting into the most prestigious ISI-ranked journals, although the greatest increases are in the least context-dependent and rhetorically demanding science fields. For many authors, then, it seems that Native-speakerness confers fewer advantages than might be supposed.

\section{Is there linguistic injustice in gatekeeping practices?}

So where does this leave claims about linguistic bias? Do editors and reviewers really stigmatize L2 authors? It is certainly the case that many journal editors have reacted to the surge of non-Anglophone submissions with some alarm. This comment from the editors of Oral Oncology expresses the wider concern:

An emerging problem facing all journals is the increasing number of submissions from non-English-speaking parts of the world, where the standard of written English may fall below the expectations of a scientific publication.

(Scully \& Jenkins, 2006) 
The editors of international applied linguistics journals interviewed by Flowerdew (2001) also noted common language problems such as surface errors, the absence of authorial voice, and nativized varieties of English, while editors of the European Journal of Cardio-Thoracic Surgery highlighted problems of word choice and syntax (Benfield \& Howard, 2000). Clearly, editors expect manuscripts to be thoroughly edited on submission (e.g. Heng Hartse \& Kubota, 2014) possibly by English teachers (Na \& Hyland, forthcoming).

Reviewers also frequently note language problems and comments on grammar, style or rhetorical conventions are frequently included in reviews (e.g. Mungra \&Webber, 2010; Kourilova, 1996). All my informants had experience of this:

Sometimes they can be quite brutal, but I know I have been sloppy and should take more care with my language. $\quad$ (NES sociology doctoral student)

Yes, reviewers may criticize our grammar. They often do this, in fact (laughs). We put it right when we revise the paper.

(Physics Assistant Prof) It is possible that the frequency of these comments, and occasionally their bluntness, may lead EAL writers to believe that language has played a decisive role in the rejection of their contributions.

But while reviewers often refer to language problems, this tends to be vague and fails to identify specific problems (e.g. Shashok, 2008; Kourilova, 1998). Certainly, in applied linguistics at least, reviewers do not typically take the non-Native speaker status of authors in account in making decisions and the quality of the language is rarely a decisive factor in rejection (Belcher, 2007; Coniam, 2012). This may also be true in other fields too, as growing numbers of non-Native speakers take on gate-keeping roles- leading to greater acceptance of non-standard forms. There may also be increasing tolerance from Anglophone journal editors (Salager-Meyer, 2008), so Rozycki and Johnson (2013), for example, found widespread use of simplified grammar in prize-winning papers published by non-Native English speakers in in IEEE journals, engineering's most prestigious publications. 
Instead, reviews of both Native and non-Native English scholars' submissions tend to strongly focus on aspects of the research itself, rather than its presentation. Looking at the comments in 40 scientific letters, for example, Gosden (2003) found that reviewers mainly addressed technical detail (27\%) and the discussion (34\%). Hewings (2004) reported that reviewers responding to submissions to the Journal of English for Specific Purposes mainly evaluated the paper's overall quality and contribution (22\%) as well as the quality of claims (19\%) and the analysis (18\%). Judgements of the papers as a whole were largely positive whereas comments on the way the paper was written and on the claims were largely negative. Looking at his own 122 reviews for the language teaching journal System over 8 years, Coniam (2012) found his negative comments most often addressed the acceptability of claims (in $80 \%$ of the reviews), the methodology (in 65\%), the sufficiency of data (60\%) and the clarity of research questions (58\%). Content and methodology also dominated critical comments in both Mungra and Webber's (2010) study of Italian scholars submitting to medical journals in English and in Mur Dueñas' (2012) sample of Spanish researchers' submissions in Finance.

Interviews with editors and studies of reviewers' comments, then, tend to find no evidence to support claims of prejudicial treatment or undue attention to language in editorial decisions. In one study which set out to look for bias against EAL writers, Belcher (2007) explored the reviewers' comments on nine papers submitted to English for Specific Purposes, three from each of the Near and Middle East, the Far East, and Latin America/ non-Anglophone Europe, together with a sample of Native-English speaker submissions. She found that only 2 reviews out of the 29 contained no comments on language or style at all, and that language was commented on more frequently than any other feature, but in no case was language alone a reason for rejection. In fact, Belcher found that reviewers comments showed that unsuccessful EAL authors' papers contained the same content and expression problems as those of rejected L1 English authors. She observes that:

For some off-network Native-English scholars, even staying in control of surface textual features seemed challenging. Thus, it appears, from this small sample, that at least some 
number of rejected papers, whether authored by EL or EIL scholars, networked or offnetworked, share many of the same shortcomings.

So some language problems might result from an author writing in a second language, but the same problems also characterize the writing of L1 users of English. In fact, Benfield and Howard's comparison of submissions to the European Journal of Cardio-Thoracic Surgery found only slightly more reviewer criticisms of writing in non-Anglophone submissions. Several editors in Flowerdew's (2001) study made similar comments, suggesting that the most salient problem in international scholars' submissions was not language fluency but a lack of resources and research writing expertise. One of my Hong Kong interviewees expressed a similar view:

I believe language is not the main concern. My gut feeling is that if they like your topic, they give you chance to resubmit. They also give very detailed comments on grammar if they really want you to get published. They will allow you to correct. But if they don't like your topic, they are more general about language. So I am confident that writing skills will not be an obstacle. Although it is not perfect and we still receive some negative comments, if your topic is interesting enough, you still have a chance to revise. (Cantonese speaker-Nursing)

I am not, of course, claiming peer review to be perfect: it is a flawed process and bias exists. Peer review is subject to human imperfections and it is unreasonable to expect it to offer an objective means of judging truth. Science is a competitive world and cases of misconduct do occur (e.g. Ernst \& Resch, 1994; Godlee, 2000) but such problems tend to be rare (e.g. Ward and Donnelly, 1998). There is, however, little evidence to support the idea that there is a widespread and systematic bias against writers whose first language is not English. Such dichotomizing conceptualizations are not only largely unfounded, they are also unhelpful: demoralizing for novice writers and offensive to the many reviewers, editors and mentors who seek to support non-anglophone authors in getting published (Casanave, 2008; Englander \& Lopez-Bonilla, 2011). 
The question of what reviewers mean by 'language' is also relevant here. Authors often remark that reviewers' comments on nonNative-like features in their manuscripts are often indefinite and unhelpful (Kourilová,1998). As Kerans points out, most reviewers

lack the metalanguage needed to talk about rhetorical problems thus... they rush to blame ‘the English' vaguely whenever they are confused by [an English L2] writer's manuscript.

(Kerans, 2001: 339).

In her study of text revisions in response to reviewers' language criticisms, for instance, Englander (2006) suggests that it is not the English that is usually the problem but that authors violate the reviewers' expectations of academic writing. It is control of the register rather than the language which is at issue. This is not to say that difficulties with English syntax, lexis or discourse do not greatly complicate the task of non-Anglophone academics, but it calls into question a coarse Native vs. nonNative dichotomy and encourages us to think beyond linguistic bias. A lack of resources and writing expertise could be far more important obstacles for both EAL and Native English authors.

\section{Some final observations}

In this paper I have sought to raise some questions about a pervasive view which asserts that EAL scholars are disadvantaged in the cut-throat competitive world of academic publishing by virtue of their status as second language writers. In recent years this view has gained the privileged position of an unchallenged orthodoxy, so that many EAL novice writers automatically invoke the stereotype of "nonNative speaker" when finding themselves vulnerable in the review process (Huang, 2010). It is, however, a framing largely based on unexamined assumptions and a lack of research into Anglophone practices.

The 'disadvantage orthodoxy' position, in fact, provides a limited picture of writing for publication and does a serious disservice to both Native and non-Native English speaking writers. It has two damaging consequences: 
1. By focusing on language shortcomings it perpetuates a myth of L2 deficit which discourages EAL authors and tells them to look for prejudice rather than revision.

2. It marginalizes the challenges faced by NES authors by depicting Kachru's Inner Circle as a kind of safe house where academic publication can be taken for granted.

Quite clearly, however, Anglophone scholars, especially those at the beginning of their careers, have to cope with the same publish or perish demands and the same arcane writing conventions to keep their jobs and climb the ladder. Put most simply, writing as an L1 English scholar does not guarantee a successful publishing career any more than working as an isolated, off-network EIL author condemn one to failure. Authorial agency and individual experience, too often ignored in these debates, are key dynamics. Aspects of isolation such as limited access to resources and rhetorical models can obviously limit publishing opportunities for both NES and EAL scholars, but individuals are not simply products of their environment and these factors need not be determining ones.

There are, I feel, important implications in all this for second language writing scholarship and practice. First, my argument aligns with the widely accepted view that we need to see L2 writing as embedded in wider social, institutional and political contexts rather than as something which exists in isolation from them. The difficulties experienced by writers of any first language are not due to deficit or negligence but broader discourse practices which are often invisible to writers, reviewers and editors. This not only points to the need for greater inclusivity in teaching, ensuring that academic writing courses target Native as well as non-Native English speaking students, but also argues against a static model of instruction where writing is simply the donkey-work done after research is completed. Writing is a way of knowing, and those who write understand it is a difficult and messy business. Exposing students to others' processes as well as others' texts may help to convey something of this and help reassure novice writers that even celebrity authors have their blocks and rejections (Hyland, 2015). Teachers seeking to distinguish issues and strategies for either monolingual or EAL scholars enrolled in English for Publication Purposes courses will find the task is by no means straightforward. 
Second, it seems clear that issues of linguistic disadvantage, or even injustice, become largely irrelevant at these advanced levels of academic writing where authors are seeking publication for their work. Here both NES and EAL novice authors are engaged in employing new and unfamiliar literacy skills to craft their texts for exacting specialist readers. It is a site where technical issues of grammatical accuracy have less relevance than rhetorical knowledge, persistence and an awareness of an authorial self. This revision of the notion of competence (or expertise) is not a new argument and readers may recognize resonances with Canagarajah's (2013) views on “the end of L2 writing” or Kobayashi and Rinnert's (2013) position that theories of multicompetence, genre, and identity, not L1 vs L2 dichotomies, can better elucidate the character of multilingual writers. What is apparent, however, is that literacy is not a single monolithic accomplishment but a series of socially situated, discipline-sensitive practices which have to be learnt as needed. Discourses are 'ways of being in the world' (Gee, 1999: 23) created from culturally available resources which involve interactions between the conventions of the literacy event, the ways that communities maintain their interests, and the values, beliefs and prior experiences of the participants. They are not part of a Native speaker heritage.

Lastly, I want to underline the important point that the current orthodoxy which attributes publishing success to mother tongue perpetuates an idealised monolingualism that still underlies a lot of thinking in applied linguistics. Languages are linguistic practices which have evolved to get things done in particular spheres and not cognitive structures existing inside the head of idealised monolingual Native speakers. Academic writing for publication is a practice of a literary elite, but it is an elite which is not restricted to Native English speakers. Scholars who publish in a second language now represent a majority, but they continue to struggle with minority status. However, attributing publication to that fact alone oversimplifies a more complex picture and does not help solve the very real problems experienced by both EAL and Native English speaking writers. 


\section{References}

Aitchison, C., Catterall, J., Ross, P., \& Burgin, S. (2012). 'Tough love and tears': learning doctoral writing in the sciences, Higher Education Research \& Development, 31(4), 435-447.

Ammon, U. (1990). German or English? The problems of choice experienced by German-speaking scientists In P. Nelde (Ed.) Language Conflict and Minorities (pp. 33-51). Bonn: Dümmler.

Badenhorst, C., Moloney, C., Rosales, J., Dyer, J., \& Ru, L. (2015) Beyond deficit: graduate student research-writing pedagogies, Teaching in Higher Education, 20(1). 1-11.

Belcher, D. (2007). Seeking acceptance in an English-only research world. Journal of Second Language Writing, 16, 1-22.

Benfield, J. (2007). Cardiothoracic surgeons divided by a common language. The Annals of Thoracic Surgery, 84, 363-364

Benfield, J. \& Howard, K. (2000). The language of science. European Journal of Cardio-Thoracic Surgery $18,642-8$.

Berkenkotter, C., \& Huckin, T. (1995). Genre knowledge in disciplinary communication. Mahwah, NJ: Lawrence Earlbaum.

Björk, B-C., Roos, A., \& Lauri, M. (2009). Scientific journal publishing: yearly volume and open access availability. Information Research, 14(1). http://InformationR.net/ir/14-1/paper391.html]

Bould M.D., Boet S., Riem N., Kasanda C., Sossou A., \& Bruppacher H.R. (2010). National representation in the anaesthesia literature: a bibliometric analysis of highly cited anaesthesia journals. Anaesthesia, 65(8), 799-804.

Burrough-Boenisch, J. (2003). Shapers of published NNS research articles. Journal of Second Language Writing, 12(3), 223-243

Cameron, J., Nairn, K., \& Higgins, J. (2009). Demystifying academic writing: reflections on emotions, know-how and academic identity. Journal of Geography in Higher Education, 33(2), 269-284. 
Canagarajah, A.S. (1996). 'Nondiscursive requirements in academic publishing, material resources of periphery scholars, and the politics of knowledge production. Written Communication, 13(4), 435472.

Canagarajah, A. S. (2013). Translingual practice: Global Englishes and cosmopolitan relations.

Abingdon: Routledge.

Casanave, C. (1998). Transitions: the balancing act of bilingual academics. Journal of Second Language Writing.,12(1), 175-203.

Casanave, C.P. (2008). The stigmatizing effect of Goffman's stigma label: a response to John Flowerdew. Journal of English for Academic Purposes, 7(4), 264-267

Casanave, C., \& Vandrick, S. (2003). Introduction: Issues in writing for publication. In Casanave, C. \& Vandriick, S. (eds). Writing for scholarly publication. Mahwah, NJ: Lawrence Earlbaum. pp $1-16$.

Cho, S. (2004). Challenges of entering discourse communities through publishing in English. Journal of Language, Identity, and Education, 3, 47-72

Clavero, M. (2010) 'Awkward wording. Rephrase': linguistic injustice in ecological journals. Trends Ecology Evolution 25, 552-553.

Coniam, D. (2012). Exploring reviewer reactions to papers submitted to academic journals. System, 40, $544-553$.

Davies, A. (2003). The Native speaker: Myth and reality. Clevedon: Multilingual Matters.

Duszak, A., \& Lewkowicz, J. (2008). Publishing academic texts in English: A Polish perspective. Journal of English for Academic Purposes, 7,108-120.

El Malik, A. T., \& Nesi, H (2008) Publishing research in a second language: The case of Sudanese contributors to international medical journals. Journal of English for Academic Purposes, 7(2), 8796. 
Englander, K. (2006). Revision of scientific manuscripts by non-Native-English-speaking scientists in response to journal editors' language critiques. Journal of Applied Linguistics, 3, 129-161.

Englander, K., \& Lopez-Bonilla, G. (2011). Acknowledging or denying membership: reviewers’ responses to non-Anglophone scientists' manuscripts. Discourse Studies, 13(4), 395-416.

Ernst E., \& Resch, KL. (1994): Reviewer bias: a blinded experimental study. Journal of Laboratory and Clinical Medicine, 124,(2), 178-82.

Escudero, P., \& Sharwood Smith, M. (2001). Reinventing the Native speaker: or 'What you never wanted to know about the Native speaker so never dared to ask.' In Foster-Cohen, S. \& Nizegorodcew, A. (eds). EUROSLA Yearbook: 1: 275-286

Ferguson, G., Pérez-Llantada, C., Plo, R. (2011) 'English as an international language of scientific publication: a study of attitudes'. World Englishes 30,1, 41-59.

Flowerdew, J. (1999). Problems in writing for scholarly publication in English: The case of Hong Kong. Journal of Second Language Writing, 8, 243-264.

Flowerdew, J. (2001). Attitudes of journal editors to non-Native speaker contributions. TESOL Quarterly, 35(1), 121-150.

Flowerdew, J. (2007). The non-Anglophone scholar on the periphery of scholarly publication. AILA Review, 20,14-27.

Flowerdew, J. (2008). Scholarly writers who use English as an Additional Language: what can Goffman's "Stigma" tell us? Journal of English for Academic Purposes, 7(2), 77-86

Gee, J. (1999). An Introduction to Discourse Analysis. London: Routledge.

Geertz, C. (1983). Local knowledge: Further essays in interpretive anthropology. New York: Basic Books.

Godlee, F. (2000). The ethics of peer review. In A. H. Jones \& F. McLellan (Eds.): Ethical issues in biomedical publication (pp. 59-84). Baltimore, MD Johns Hopkins University Press. 
Gosden, H. (1992). Research writing and NNSs: From the editors. Journal of Second Language Writing, $1(2), 123-139$.

Gosden, H. (1995). Success in research article writing and revision: a social-constructionist perspective. English for Specific Purposes, 13, 37-57.

Gosden, H. (2003). Why not give us the full story? Functions of referees' comments in peer reviews of scientific research papers. Journal of English for Academic Purposes, 2, 87-101.

Graddol, D. (2000). The future of English? London: The British Council.

Guardiano, C., Favilla, M., \& Calaresu, E. (2007). Stereotypes about English as the language of science. AILA Review, 20, 28-52.

Habibie, P. (2015). Writing for scholarly publication in Canadian higher education context: a case study. In C. M. Badenhorst \& C. Guerin (Eds.), Post/graduate research literacies and writing pedagogies. Leiden: Brill Publishing

Hanauer, D., \& Englander, K. (2011). Quantifying the burden of writing research articles in a second language. Data From Mexican scientists. Written Communication, 28(4), 403-416.

Heng Hartse, J., \& Kubota, R. (2014). Pluralizing English? Variation in high-stakes academic texts and challenges of copyediting. Journal of Second Language Writing, 24, 71-82.

Hewings, M. (2002). A history of ESP through English for Specific Purposes. English for Specific Purposes World: A Web based Journal, 1(3). Published at http://www.espworld.info/Articles_3/Hewings_paper.htm.

Hewings, M. (2004). An 'important contribution' or 'tiresome reading'? A study of evaluation in peer reviews of journal article submissions. Journal of Applied Linguistics, 1(3), 247-274.

Huang, J.C. (2010). Publishing and learning writing for publication in English: Perspectives of NNES PhD students in science. Journal of English for Academic Purposes, 9(1), 33-44.

Hudson, R.A. (1996). Sociolinguistics ( $2^{\text {nd }}$ ed). Cambridge: Cambridge University Press.

Hwang, K. (2005) The inferior science and the dominant use of English in knowledge production. A case study of Korean science and technology. Science Communication, 26(4), 390-427. 
Hyland, K. (2011). Projecting an academic identity in some reflective genres. Iberica. 21: 9-30

Hyland, K. (2015). Academic publishing: Issues and challenges in the construction of knowledge. Oxford: OUP.

Kerans, M.E. (2001) Eliciting substantive revision of manuscripts for peer review. In Munoz, C. (Ed.). Trabajos en linuistica Aplicada. Barcelona: Univerbook: 339-248.

Kobayashi, H., \& Rinnert, C. (2013). L1/L2/L3 Writing Development: Longitudinal Case Study of a Japanese Multicompetent Writer. Journal of Second Language Writing, 22 (1) p4-33

Kourilova, M. (1996). Interactive function of language in peer reviews of medical papers written by NN users of English. UNESCO-ALSED LSP Newsletter, 19 (1): 4-21.

Kourilová, M. (1998). “Communicative characteristics of reviews of scientific papers written by nonNative users of English”. Endocrine Regulations 32: 107-114.

Li, Y. (2002). Writing for international publication: The perception of Chinese doctoral researchers. Asian Journal of English Language Teaching, 2002, 12, 179-193.

Li, Y-Y. (2006). “A doctoral student of Physics writing for publication; a socio-politically-oriented case study". English for Specific Purposes 25: 456-478.

Lillis, T., \& Curry, M.J. (2010). Academic writing in a global context. London: Routledge

Liu, J. (2004). Co-constructing academic discourse from the periphery: Chinese applied linguists' centripetal participation in scholarly publication. Asian Journal of English Language Teaching, 14: $1-22$

Loi, C.K. (2010). Research article introductions in Chinese and English: A comparative genre-based study Journal of English for Academic Purposes, 9, 4, 267-279

Love, N., \& Ansaldo, U. (2010). The Native speaker and the mother tongue. Language Sciences 32 (6): $589-593$. 
Man, J., Weinkauf, J., Tsang, M., \& Sin, J. (2004). Why do Some Countries Publish More Than Others? An International Comparison of Research Funding, English Proficiency and Publication Output in Highly Ranked General Medical Journals. European Journal of Epidemiology. 19(8): 811-817

Moreno, A., Rey-Rocha, J., Burgess, S., López-Navarro, I., \& Sachdev, I. (2012). Spanish researchers' perceived difficulty writing research articles for English medium journals: the impact of proficiency in English versus publication experience. Ibérica 24 (2012): 157-184

Mungra, P. \&Webber, P. (2010). Peer review process in medical research publications: language and content comments. English for Specific Purposes. 29, 43-53.

Mur Dueñas, P. (2012). Getting research published internationally in English: An ethnographic account of a team of Finance Spanish scholars' struggles. Ibérica 24: 139-156

Murray, H., \& S. Dingwall (2001). The dominance of English at European universities: Switzerland and Sweden compared in U. Ammon (ed.), 85-112.

Myers, G. (1990). Writing Biology: Texts in the Social Construction of Scientific Knowledge. Madison, WI: University of Wisconsin Press.

Na, L., \& Hyland, K. (forthcoming). Chinese academics writing for publication: English teachers as text mediators.

Oermann, M. H., \& Hays, J. C. (2011). Writing for publication in nursing. (2nd ed.). New York: Springer

Okike K., Kocher, M.S., Mehlman, C.T., Heckman, J.D., Bhandari, M. (2008). Nonscientific factors associated with acceptance for publication in The Journal of Bone and Joint Surgery. Journal of Bone and Joint Surgery Am. 90: 2432-2437.

Pagel, W.J., Kendall, F.E., \& and Gibbs, H.R. (2002). Self-Identified Publishing Needs of NonNative English-Speaking Faculty and Fellows at an Academic Medical Institution. Science Editor. 25 (4) $111-114$ 
Patel V., \& Youl-ri, K. (2007). Contribution of low- and middle-income countries to research published in leading general psychiatry journals, 2002-2004. British Journal of Psychiatry, 190, 77-78.

Perez-Llantada, C. (2014). Scientific Discourse and the Rhetoric of Globalization . London: Bloomsbury.

Rohra, D.K. (2011). Representation of less-developed countries in Pharmacology journals: an online survey of corresponding authors. BMC Medical Research Methodology. 11:60

Römer, U. (2009). English in academia: does Nativeness matter? Anglistik: International Journal of English Studies, 20(2), 89-100.

Ross, J.S., Gross, C.P., Desai, M.M., Hong, Y., Grant, A.O., Daniels, S.R. (2006). Effect of blinded peer review on abstract acceptance. JAMA, 295, 1675-1680.

Royal Society, The (2011). Knowledge, networks and nations: Global scientific collaborations in the 21 st century, (RS Policy document 03/11).

Rozycki, W., \& Johnson, N. (2013). Non-canonical grammar in Best Paper award winners in engineering. English for Specific Purposes. 32 (3): 157-169.

Salager-Meyer, F. (2008). Scientific publishing in developing countries: challenges for the future". Journal of English for Academic Purposes. 7: 121-132.

Saposnik, G., Ovbiagele, B., Raptis, S., Fisher, M., \& Johnston, S.C. (DATE?) Effect of English Proficiency and Research Funding on Acceptance of Submitted Articles to Stroke Journal. Stroke, 45: pp 1862-1868

SCImago. (2014). Journal and country rank. http://www.scimagojr.com/countryrank.php

Scully, C., \& Jenkins, S. (2006). Editorial: Publishing in English for non-Native speakers Oral Oncology. 42 (7), 753.

Shashok, K. (2008). Content and communication: How can peer review provide helpful feedback about the writing? BMC Medical Research Methodology 8:3 doi:10.1186/1471-2288-8-3

Shirey, M. (2013). Building scholarly writing capacity in the doctor of nursing practice program. Journal of Professional Nursing, 29 (3): 137-147. 
Singh, D. (2006). Publication bias- a reason for the decreased research output in developing countries. South African Psychiatry Review 9: 153-155.

St John, M. J. (1987) Writing processes of Spanish scientists publishing in English. English for Specific Purposes. 6: 113-120

Swales, J. M. (1990). Genre analysis: English in academic and research settings. Cambridge: Cambridge University Press,.

Swales, J. M. (2004). Research Genres. Cambridge: Cambridge University Press.

Tardy, C. (2004). "The role of English in scientific communication: lingua franca or tyrannosaurus rex?". Journal of English for Academic Purposes, 3, 247-269.

Thomson-Reuters (2012). Global publishing: Changes in submission trends and the impact on scholarly publishers.

Tijssen, R.J.W. (2007). Africa's contribution to the worldwide research literature: New analytical perspectives, trends, and performance indicators. Scientometrics, 71(2): 303-327

Ward J.E., Donnelly, N. (1998). Is there gender bias in research fellowships awarded by the NHMRC? Medical Journal of Australia, 169, 623-624.

Ware, M., \& Mabe, M. (2009). The STM Report: an overview of scientific and scholarly publishing. Oxford, STM: International Association of Scientific, Technical and Medical Publishers.

Wood, A. (2001). International scientific English: The language of research scientists around the world. In J. Flowerdew, \& M. Peacock (Eds.), Research perspectives on English for academic purposes (pp. 81-83). New York: Cambridge University Press.

World Bank (2012). Annual Report. http://siteresources.worldbank.org/EXTANNREP2012/Resources/87844081346247445238/AnnualReport2012_En.pdf

Yousefi-Nooraie, R., Shakiba, B., \& Mortaz-Hejri S. (2006). Country development and manuscript selection bias: a review of published studies. BMC Medical Research Methodology, 6, 37. 